\title{
Transpiration and stomatal conductance across a steep climate gradient in the southern Rocky Mountains
}

\author{
Nate G. McDowell, ${ }^{1 *}$ Sandra White ${ }^{2}$ and William T. Pockman ${ }^{2}$ \\ ${ }^{1}$ Earth and Environmental Sciences Division, Los Alamos National Laboratory, Los Alamos, NM 87544, USA \\ ${ }^{2}$ Department of Biology, University of New Mexico, Albuquerque, NM 87131, USA
}

\begin{abstract}
Transpiration $(E)$ is regulated over short time periods by stomatal conductance $\left(G_{\mathrm{s}}\right)$ and over multi-year periods by treeand stand-structural factors such as leaf area, height and density, with upper limits ultimately set by climate. We tested the hypothesis that tree structure, stand structure and $G_{\mathrm{s}}$ together regulate $E$ per ground area $\left(E_{\mathrm{g}}\right)$ within climatic limits using three sites located across a steep climatic gradient: a low-elevation Juniperus woodland, a mid-elevation Pinus forest and a high-elevation Picea forest. We measured leaf area : sapwood area ratio $\left(A_{1}: A_{\mathrm{s}}\right)$, height and ecosystem sapwood area : ground area ratio $\left(A_{\mathrm{s}}: A_{\mathrm{g}}\right)$ to assess long-term structural adjustments, tree-ring carbon isotope ratios $\left(\delta^{13} \mathrm{C}\right)$ to assess seasonal gas exchange, and whole-tree $E$ and $G_{\mathrm{s}}$ to assess short-term regulation. We used a hydraulic model based on Darcy's law to interpret the interactive regulation of $G_{\mathrm{s}}$ and $E_{\mathrm{g}}$. Common allometric dependencies were found only in the relationship of sapwood area to diameter for pine and spruce; there were strong site differences for allometric relationships of sapwood area to basal area, $A_{1}: A_{\mathrm{s}}$ and $A_{\mathrm{s}}: A_{\mathrm{g}}$. On a sapwood area basis, $E$ decreased with increasing elevation, but this pattern was reversed when $E$ was scaled to the crown using $A_{\mathrm{l}}: A_{\mathrm{s}} . E_{\mathrm{g}}$ was controlled largely by $A_{\mathrm{s}}: A_{\mathrm{g}}$, and both $E_{\mathrm{g}}$ and $G_{\mathrm{s}}$ declined from high- to low-elevation sites. Observation-model comparisons of $E_{\mathrm{g}}, G_{\mathrm{s}}$ and $\delta^{13} \mathrm{C}$ were strongest using the hydraulic model parameterized with precipitation, vapour pressure deficit, $A_{\mathrm{l}}: A_{\mathrm{s}}$, height, and $A_{\mathrm{s}}: A_{\mathrm{g}}$, supporting the concept that climate, $G_{\mathrm{s}}$, tree- and stand-structure interact to regulate $E_{\mathrm{g}}$. Copyright (C) 2008 John Wiley \& Sons, Ltd.
\end{abstract}

KEY WORDS altitude; gas exchange; carbon isotopes; sap flow; water availability

Received 24 December 2007; Accepted 7 June 2008

\section{INTRODUCTION}

Trees regulate transpiration $(E)$ via both short-term changes in crown-scale stomatal conductance $\left(G_{\mathrm{s}}\right)$ in response to variation in light, vapour pressure deficit and leaf water potential, and longer-term changes in canopy leaf area and the structure of the roots and shoots that supply the canopy with water. Diurnal to seasonal variation in $G_{\mathrm{s}}$ avoids cavitation-inducing xylem pressures while maximizing $\mathrm{CO}_{2}$ diffusion into foliage (Cowan and Farquhar, 1977; Katul et al., 2003). At annual to decadal timescales, adjustment of leaf area to sapwood area ratios $\left(A_{1}: A_{\mathrm{s}}\right)$, with or without accompanying changes in stomatal regulation of transpiration, may also effectively minimize cavitation while maximizing photosynthetic surface area (Waring, 1980; Mencuccini, 2003; McDowell et al., 2006). Other within-tree structural factors such as the amount of sapwood held within stems (Meinzer et al., 2001; Ewers et al., 2002) and tree height (Addington et al., 2006) are also adjusted to maximize $G_{\mathrm{s}}$ within limits imposed by site water availability. Finally, at decadal to century timescales, the amount of sapwood area per unit ground area $\left(A_{\mathrm{s}}: A_{\mathrm{g}}\right)$ and leaf area index (LAI) vary as a function of climate and edaphic characteristics, again balancing carbon gain relative to cavitation

\footnotetext{
* Correspondence to: Nate G. McDowell, Earth and Environmental Sciences Division, Los Alamos National Laboratory, Los Alamos, NM 87544, USA. E-mail: mcdowell@lanl.gov
}

risk. The interaction of these short- and long-term factors has been shown to regulate leaf internal $\mathrm{CO}_{2}$ concentration, and hence, water use efficiency, as a homeostatic set point (Ehleringer, 1993; McDowell et al., 2006). Thus, the interaction of $G_{\mathrm{s}}$ and structural factors is ideally considered within an ecohydrological framework because surface hydrology regulates $G_{\mathrm{s}}, E$ and subsequent gross primary production, which feeds back on water balance at the individual, ecosystem and watershed scales (Waring and Schlesinger, 1985).

Theoretical predictions of the dependence of $E$ on $G_{\mathrm{s}}$ $\left(\right.$ mols area $^{-1}$ time $\left.^{-1}\right)$ and tree and stand structures can be captured using a simplified hydraulic corollary to Darcy's law (Whitehead and Jarvis, 1981):

$$
G_{\mathrm{s}}=\frac{A_{\mathrm{s}} k_{\mathrm{s}}\left(\Psi_{\mathrm{s}}-\Psi_{\mathrm{l}}\right)}{h \eta A_{1} D},
$$

in which $A_{\mathrm{s}}$ is sapwood area $\left(\mathrm{m}^{2}\right), A_{\mathrm{l}}$ is leaf area $\left(\mathrm{cm}^{2}\right)$, $k_{\mathrm{S}}$ is specific conductivity of the xylem $\left(\mathrm{m} \mathrm{s}^{-1}\right), \Psi_{\mathrm{s}}$ is soil water potential (MPa), $\Psi_{1}$ is daytime leaf water potential, $h$ is tree height $(\mathrm{m}), \eta$ is water viscosity ( $\mathrm{Pa} \mathrm{s})$, and $D$ is vapour pressure deficit ( $\mathrm{kPa}$ ) (Whitehead et al., 1984; Whitehead, 1998). The hydraulic model can be re-written to predict $E$ per unit leaf area $\left(E_{1}, \mathrm{mmol} \mathrm{m}^{-2}\right.$ leaf day $\left.^{-1}\right)$ because:

$$
E=G_{\mathrm{s}} \bullet D
$$

when leaves are well coupled to the atmosphere, as is typically the case for needle leaf species. This framework 
may be applied to ecosystem-scale predictions of $E$ per unit ground area $\left(E_{\mathrm{g}}, \mathrm{mmol} \mathrm{m} \mathrm{m}^{-2}\right.$ ground $\left.\mathrm{day}^{-1}\right)$, by combining Equations (1) and (2) and multiplying by LAI (i.e. $A_{1}: A_{\mathrm{g}}, \mathrm{m}^{2} \mathrm{~m}^{-2}$ ), yielding:

$$
E_{\mathrm{g}}=\frac{A_{\mathrm{s}} k_{\mathrm{s}}\left(\Psi_{\mathrm{s}}-\Psi_{1}\right)}{h \eta A_{\mathrm{g}}}
$$

More complex physiological models of water transport exist (e.g. Williams et al., 1996; Sperry et al., 2002); however, the hydraulic model represented by Equation (1) has proven useful to interpret the interaction of short-term physiological and long-term structural regulation of $E$ in relation to tree size (Ryan et al., 2000; Schäfer et al., 2000; McDowell et al., 2002a,b, 2005; Phillips et al., 2002; Barnard and Ryan, 2003) and stand density (Whitehead et al., 1984; McDowell et al., 2006). The hydraulic model has been successfully tested in multi-species comparisons (Oren et al., 1999; Ewers et al., 2005, 2007). To our knowledge, the hydraulic model has not been used to generate hypotheses regarding variation or controls over $E$ across multi-species elevation gradients at the watershed scale. Elevation transects provide a challenging test of our understanding of the fundamental properties regulating $E$ because uncontrolled variation in species composition, edaphic properties, climate and disturbance history can affect predictions of $G_{\mathrm{s}}$ and $E$ from Equations (1) to (3). Thus, the enormous variability across elevation transects provides a challenging test of our understanding of the fundamental properties regulating $E$.

In theory, the general framework in Equations (1)-(3) allows us to predict relative variation in $G_{\mathrm{s}}$ and $E$ across a watershed given knowledge of relative variation in $D$ and $\Psi_{\mathrm{s}}-\Psi_{1}$. Assuming for now that $A_{1}: A_{\mathrm{s}}$, tree height and other tree structural parameters of Equation (1) vary to maximize carbon gain while minimizing cavitation, the hydraulic model predicts that a decline in $\Psi_{\mathrm{s}}$, such as with decreasing elevation in the southern Rocky Mountains, will lead to an exponential relationship between $G_{\mathrm{s}}$ and $D$ (Figure 1 solid line). In this general model, we hold $\Psi_{1}$ constant as is typical of isohydric species (Oren et al., 1999; Hubbard et al., 2001; Ewers et al., 2007) and set $\Psi_{\mathrm{s}}$ to decline at a rate of $-0.2 \mathrm{MPa}$ for every $1 \mathrm{kPa}$ increase in $D$, such that $\Psi_{\mathrm{s}}-\Psi_{1}$ ranges from 1 to 0 . At the ecosystem scale, if we assume that stand-structural parameters such as stand density vary in a space-filling manner (Enquist and Niklas, 2001) so that $G_{\mathrm{s}}$, leaf area and sapwood area will be maximized within the climate envelope, then the general model predicts $E_{\mathrm{g}}$ will decline linearly with increasing $D$ (Figure 1 dashed line) and that this decline is driven primarily by $A_{\mathrm{s}}: A_{\mathrm{g}}$ (Ewers et al., 2002). The predictions shown in Figure 1 can be refined with direct measurements of key variables such as $A_{\mathrm{l}}: A_{\mathrm{s}}, A_{\mathrm{s}}: A_{\mathrm{g}}$ and $G_{\mathrm{s}}$, and as such, the regulatory role of $G_{\mathrm{s}}$, tree- and stand-structural parameters on $E$ can be examined.

We tested the theory that adjustments of $G_{\mathrm{s}}$ and treeand stand-level structure maximize $E$ within limits governed ultimately by evaporative demand and precipitation

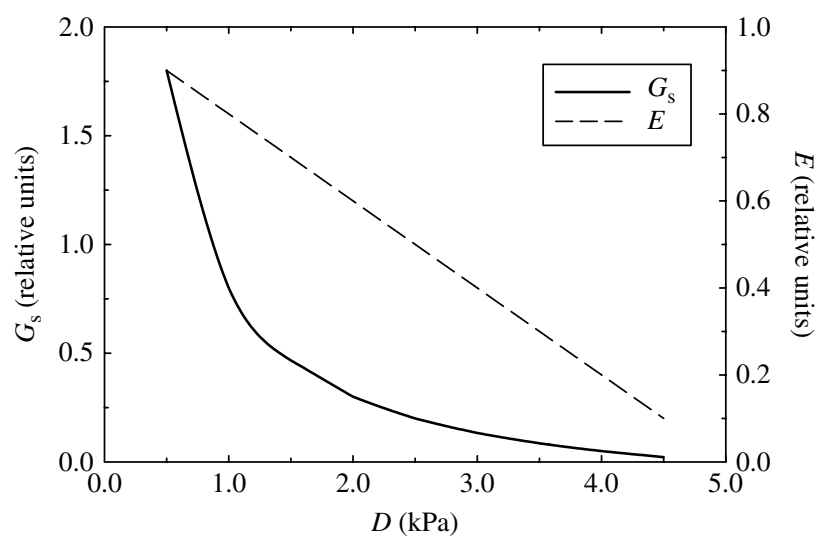

Figure 1. The theoretical relationship between $E$ and $D$ (solid line) and between $G_{\mathrm{s}}$ and $D$ (dashed line) based on Equation (1).

(Figure 1) when examined across a steep climate gradient. We used two sites from the Sustainability of SemiArd Hydrology and Riparian Areas ecohydrology effort within the upper Rio Grande watershed funded by the National Science Foundation (Brooks and Vivoni, 2008) along with a third site to extend the transect into lower elevation, more arid climate. The sites ranged from a lowelevation juniper woodland to a sub-alpine forest located at high elevation. This was a challenging test because the three sites varied in climate, species composition, edaphic conditions, and disturbance history. Specifically, we tested the hypothesis that the relationships shown in Figure 1 for $G_{\mathrm{s}}$ and $E$ would match observations across the elevation transect.

\section{METHODS}

\section{Study sites and experimental design}

The experimental sites are located in the Rio Grande Basin of northern New Mexico. Two of the sites are located within the Jemez River watershed and are described by Brooks and Vivoni (2008). Briefly, they are a spruce (Picea englemanii) stand located in the Valle Caldera National Preserve $\left(35^{\circ} 53^{\prime} 21^{\prime \prime} \mathrm{N}, 106^{\circ} 31^{\prime} 56^{\prime \prime} \mathrm{W}\right.$, $3046 \mathrm{~m}$ a.s.l.) and a ponderosa pine (Pinus ponderosa) stand also located in the Valle Caldera $\left(35^{\circ} 51^{\prime} 53^{\prime \prime} \mathrm{N}\right.$, $106^{\circ} 35^{\prime} 46^{\prime \prime} \mathrm{W}, 2499 \mathrm{~m}$ a.s.l.). The spruce site is located on a ridge and has shallow soils whereas the pine site is located in a valley bottom with deep soils (Brooks and Vivoni, 2008). The third site is located just east of the caldera on the Pajarito Plateau. This site is a juniper (Juniperus monosperma) woodland located at Los Alamos National Laboratory $\left(35.85^{\circ} \mathrm{N}, 106.27^{\circ} \mathrm{W}\right.$, $2140 \mathrm{~m}$ a.s.1.). The juniper trees at this site were sympatric with piñon pine (Pinus edulis) until a mortality event in which $\sim 97 \%$ of the mature piñon trees died in October 2002 (Breshears et al., 2005; McDowell et al., 2008). The over-story is dominated by juniper, with a minor component of piñon and oak (Quercus undulata). The under-story is dominated by native grasses (Bouteloua gracilis) and forbs that have invaded since 
the piñon mortality. The site is located on a $\sim 200-\mathrm{m}-$ wide mesa with a slope of $\sim 5 \%$. The soils are a Hackroy clay loam derived from volcanic tuff, with depths ranging from 30 to $130 \mathrm{~cm}$. This has been the site of extensive research on soil moisture and ecology (e.g. Lajtha and Getz, 1993; Breshears et al., 1997; Rich et al., 2007). The climate at all three sites is continental with warm summers and cold winters, with subsequent moderation by elevation (Table I). Annual precipitation at each site exhibits a bimodal distribution between winter snowfall and summer monsoon showers. The data presented in this article are from a study period lasting from 26 July to 28 September 2005 (days of the year: 207-271).

We used repeated measures analysis of variance to test for site differences in $E$ (per unit sapwood, leaf and ground area) and $G_{\mathrm{s}}$. Regression was used for allometric analyses and analysis of variance was used for carbon isotope comparisons between sites. All statistical analyses were conducted with Systat 11.0 (Systat Inc, San Jose, CA).

\section{Stand-structural characteristics}

We conducted field surveys at each site to determine the stand-structural characteristics of sapwood area per unit ground area $\left(A_{\mathrm{s}}: A_{\mathrm{g}}\right)$ and LAI in order to understand how ecosystem-scale variation in structure impacts transpiration per unit ground area $\left(E_{\mathrm{g}}\right)$. At the juniper site, a 1.5-ha plot installed in 1987 has been routinely monitored for vegetation demographics (Breshears et al., 2005; Rich et al., 2007). As of 2005, the year of this study, the plot contained 557 live juniper individuals and 22 live piñons (McDowell et al., 2008). Junipers are often multistemmed with branching of the stems originating near the

Table I. Site characteristics and results with one standard error in parentheses.

\begin{tabular}{|c|c|c|c|}
\hline Parameter & juniper & pine & spruce \\
\hline MAP (cm) & 40 & 60 & 93 \\
\hline MAT $\left({ }^{\circ} \mathrm{C}\right)$ & 11 & 4.9 & $4 \cdot 1$ \\
\hline MAD (kPa) & 0.95 & 0.41 & 0.40 \\
\hline ST $\left({ }^{\circ} \mathrm{C}\right)$ & 19.4 & $12 \cdot 7$ & $11 \cdot 7$ \\
\hline $\mathrm{SD}(\mathrm{kPa})$ & $1 \cdot 87$ & 1.09 & $1 \cdot 24$ \\
\hline Stems ha $^{-1}$ & 834 & $1041(332)$ & 783 (259) \\
\hline Basal area $\left(\mathrm{m}^{2} \mathrm{ha}^{-1}\right)$ & $10 \cdot 5$ & $49(4.9)$ & $45(6 \cdot 5)$ \\
\hline Diameter $(\mathrm{cm})$ & $10 \cdot 0(0 \cdot 25)$ & $25 \cdot 0(2 \cdot 2)$ & $26 \cdot 9(2 \cdot 5)$ \\
\hline Height (m) & $2 \cdot 7(0 \cdot 3)$ & $21.3(0.7)$ & $19.6(0.9)$ \\
\hline$A_{1}: A_{\mathrm{s}}\left(\mathrm{m}^{2} \mathrm{~cm}^{-2}\right)$ & $0.24(0.03)$ & $0.05(0.01)$ & $0.09(0.01)$ \\
\hline$A_{\mathrm{s}}: A_{\mathrm{g}}\left(\mathrm{m}^{2} \mathrm{ha}^{-1}\right)$ & $2 \cdot 5$ & $47 \cdot 5(4 \cdot 7)$ & $34 \cdot 3(5 \cdot 0)$ \\
\hline $\mathrm{LAI}\left(\mathrm{m}^{2} \mathrm{~m}^{-2}\right)$ & 0.57 & $2 \cdot 38(0 \cdot 23)$ & $3.09(0.50)$ \\
\hline$p_{\mathrm{a}}-p_{\mathrm{c}}(\mathrm{Pa})$ & $16 \cdot 25(0 \cdot 23)$ & $12.94(0.33)$ & $13 \cdot 40(0 \cdot 14)$ \\
\hline
\end{tabular}

MAP, MAT and MAD represent mean annual precipitation, temperature and vapour pressure deficit for 2005. ST and SD represent the mean temperature and vapour pressure deficit during the study period of September 2005. The juniper plot is a single, 1.5 ha plot that was measured in its entirety, hence there are no standard errors for stand density, basal area or LAI measurements. Diameter is measured at breast height $(1.37 \mathrm{~m})$ for the pine and spruce trees, and at the root crown for junipers. LAI is for the dominant over-story species and is calculated from site-specific $A_{\mathrm{l}}: A_{\mathrm{S}}$ and $A_{\mathrm{S}}: A_{\mathrm{g}}$ measurements. ground surface. At our site, roughly $57 \%$ of the individuals have two or more stems. Diameter at the root crown was recorded for all stems. For both the pine and spruce sites, we installed three $400 \mathrm{~m}^{2}$ plots along a north-south running transect that included the trees monitored for sap flow within the middle plot. The number and diameter of stems were recorded within all plots. Results of these surveys are presented in Table I.

\section{Whole-tree allometrics}

In July (juniper) and August (pine and spruce) 2005, we harvested ten trees at each site to develop allometric relationships for prediction of whole-tree leaf area from sapwood area at breast height (i.e. $A_{\mathrm{l}}: A_{\mathrm{s}}$ ). For the pine and spruce sites, whole-tree leaf area was estimated by scaling branch estimates of leaf area to the canopy (Maguire and Batista, 1996; Monserud and Marshall, 1999; McDowell et al., 2002b, 2006). The junipers were small enough that entire plants were harvested and processed to develop allometric relationships between stem diameter (at breast height), sapwood area and leaf area. For the pine and spruce sites, we harvested branches immediately after each tree was felled to prevent any needle loss due to desiccation. Ten branches were harvested from throughout the height continuum of the crown for each of five trees per plot. Branches were harvested from all aspects although previous research found no effect of aspect (McDowell et al., 2002b). One or two sub-samples of fresh foliage were randomly removed from each branch and stored in a plastic bag and a cooler and then transported to the laboratory to determine specific leaf area $\left(S, \mathrm{~cm}^{2} \mathrm{~g}^{-1}\right)$. Projected leaf area was determined using a flatbed leaf area meter (LiCor LI-3100 Area Meter) calibrated to $0.01 \mathrm{~cm}^{2}$ with repeated measurements of calibration standards ranging from 1 to $3 \mathrm{~cm}^{2}(n=30)$. The remaining foliage mass for each branch $\left(M_{\mathrm{b}}\right)$ was collected in industrial-size paper bags and transported back to the laboratory where it was dried at $65^{\circ} \mathrm{C}$ for $48 \mathrm{~h}$ and weighed to the nearest $0.1 \mathrm{~g}$ after the weight had stabilized. Foliage from the juniper stems was processed identically to the methods described above. The twig subtending foliage is green for junipers, so we defined foliage as all leaf material including the green section of stem.

Based on previous results (Hubbard et al., 1999; Fischer et al., 2002; McDowell et al., 2002b, 2006), we used branch diameter $(d, \mathrm{~mm})$ to estimate $M_{\mathrm{b}}(\mathrm{g})$ for the pine and spruce trees. We examined linear and non-linear relationships including those with and without a zero intercept, and always chose the simplest possible relationship if the fit statistics were similar. Scatterplots of $M_{\mathrm{b}}$ versus $d$ revealed that variance in $M_{\mathrm{b}}$ did not consistently increase with larger values of $d$ and the relationships were linear, therefore we used standard regression rather than weighted regression (Monserud and Marshall, 1999; McDowell et al., 2002b). The $d-M_{\mathrm{b}}$ regressions are: pine $M_{\mathrm{b}}=13.25 \times d-143.55\left(r^{2}=0.68, P<0.01, n=75\right.$ branches $)$; and spruce $M_{\mathrm{b}}=11.4 \times d-129.95\left(r^{2}=\right.$ 
$0.51, P<0.01, n=104$ branches). Juniper $A_{1}$ was quantified for entire stems, so a $d-M_{\mathrm{b}}$ relationship was not necessary.

We used species-specific $d-M_{\mathrm{b}}$ regressions to scale $M_{\mathrm{b}}$ up to the entire crown for each of the sample trees. This scaling was done using measurements of $d$ on every live branch for every tree immediately after the tree was felled. We used calipers to measure $d 20 \mathrm{~mm}$ distal to the main stem in two perpendicular directions for all branches, and averaged the two values for subsequent analyses. Significant relationships between leaf area and weight were used to determine specific leaf area $(S)$ for all species. $S$ averaged $16.5 \mathrm{~cm}^{2} \mathrm{~g}^{-1}$ (standard error 0.64 , $r^{2}=0.86, P<0.01$ ), $26.4 \mathrm{~cm}^{2} \mathrm{~g}^{-1}$ (se $0.4, r^{2}=0.79$, $P<0.01$ ) and $23.9 \mathrm{~cm}^{2} \mathrm{~g}^{-1}$ (se $0.2, r^{2}=0.91, P<$ 0.01 ) for juniper, pine and spruce, respectively. There was no significant relationship between $S$ and $d$ for any site (mean $r^{2}=0.003$ ). We multiplied mean $S$ values for each tree by whole-tree leaf mass to determine whole-tree leaf area $\left(A_{1}\right)$. Occasionally, the predictions of branch leaf area were negative when branches had extremely small diameters. Negative leaf areas for such branches were set to zero, which has little effect on the wholetree estimates because these branches held relatively little foliage (McDowell et al., 2006). For juniper trees, we multiplied stem $S$ by total stem leaf mass to obtain total stem $A_{1}$.

Sapwood area was estimated from the stemwood cross-sections for each tree of all three species. The sapwood-heartwood boundary was usually clear; however, we applied bromocresol green stain (Kutscha and Sachs, 1962) to verify visual estimates. On each crosssection, the sapwood depth was measured for four cambium-to-heartwood transects located at right angles to each other, with a random start location for the first transect. Sapwood depths were averaged and sapwood area was estimated assuming concentric circularity for the pine and spruce trees. For the harvested juniper stems, we traced the outline of the sapwood cross-section onto transparency paper and then measured the entire area contained within the trace using the same leaf area meter as used for the foliage leaf areas. This approach is necessitated for juniper stems because they are not concentric. Calibration disks were made specifically for the sapwood area measurements, and we estimate precision at $1.1 \mathrm{~cm}^{2}$ based on 10 measurements each of 7 calibration disks that range from 4 to $80 \mathrm{~cm}^{2}$ (the general range of sapwood areas, $n=70)$. $A_{1}: A_{\mathrm{s}}$ was calculated from tree-specific $A_{\mathrm{l}}$ and $A_{\mathrm{s}}$ measurements for each site.

\section{Stemwood carbon isotope ratios}

We used carbon isotope ratios $\left(\delta^{13} \mathrm{C}\right)$ of the 2004 tree ring from all three sites as an independent assessment of the variation in crown-scale gas exchange between sites. We removed fine grain particles of wood from the 2004 ring of each stem cookie from the pine and spruce sites using a dremel tool with a $3 / 32^{\prime \prime}(2.38 \mathrm{~mm})$ diameter diamond bit. We removed wood from a $3-10 \mathrm{~cm}$ circumferential path along the ring, starting at a location where the ring was sufficiently wide to ensure no cross-year contamination. The path along the ring should have reduced $\delta^{13} \mathrm{C}$ variability due to circumferential variation (Leavitt and Long, 1984, 1988). We did not attempt to separate early wood from late wood (Livingston and Spittlehouse, 1996; Leavitt and Wright, 2002) because our objective was to examine the annually integrated variation in $\delta^{13} \mathrm{C}$ across sites. We did not extract cellulose prior to measurement of $\delta^{13} \mathrm{C}$ because: (1) numerous studies have reported constant relationships between cellulose and whole-wood $\delta^{13} \mathrm{C}$ for sapwood (Livingston and Spittlehouse, 1996; Marshall and Monserud, 1996; MacFarlane et al., 1999; Loader et al., 2003; Harlow et al., 2006); (2) most cross-ring contamination is associated with carbon movement from the sapwood into the heartwood (S. Leavitt personal communication) and all of our sample rings were located within the sapwood; and (3) Equations (4) and (5) were designed for foliar gas exchange, and whole-wood has undergone less metabolic processing post-assimilation than cellulose per se (Hill et al., 1995). The fine dust collected from each ring was analysed on a Eurovector Elemental Analyzer coupled to a Micromass Isoprime isotope ratio mass spectrometer operated in continuous flow mode at Los Alamos National Laboratory's Stable Isotope Lab. Nitrous oxide was removed by gas chromatography (GC) and corrections for ${ }^{17} \mathrm{O}$ (Craig, 1957) were done for all runs. Overall precision for $\delta^{13} \mathrm{C}$ was $0.05 \%$ ( $n=41$ standards).

Tree ring $\delta^{13} \mathrm{C}$ was converted to $\Delta$ (Farquhar et al., 1982):

$$
\Delta \approx \frac{\delta^{13} \mathrm{C}_{\mathrm{a}}-\delta^{13} \mathrm{C}}{1+\delta^{13} \mathrm{C} / 1000}
$$

We obtained annual atmospheric stable carbon isotope ratios $\left(\delta^{13} \mathrm{C}_{\mathrm{a}}\right)$ from the Institute for Arctic and Alpine Research (INSTAAR) at the University of Colorado and the National Oceanic and Atmospheric Administration (NOAA), Earth System Research Laboratory (ESRL). Equation (4) corrects for annual depletion of $\delta^{13} \mathrm{C}_{\mathrm{a}}$ associated with fossil fuel emissions of $\mathrm{CO}_{2}$ depleted in $\delta^{13} \mathrm{C}$ (Leavitt and Long, 1988). This correction is necessary because a change in the $\delta^{13} \mathrm{C}_{\text {of }} \mathrm{CO}_{2}$ used as the substrate for photosynthesis causes a physiologically independent change in the $\delta^{13} \mathrm{C}$ of plant material.

An additional correction of $\delta^{13} \mathrm{C}$ data must be considered when comparing sites differing in elevation because atmospheric pressure declines as elevation increases. We calculated the partial pressure of $\mathrm{CO}_{2}$ at the leaf surface $\left(p_{\mathrm{a}}\right)$ and within the chloroplast $\left(p_{\mathrm{c}}\right)$ using the method of Hultine and Marshall (2000). We used global mean $\mathrm{CO}_{2}$ concentration data from NOAA-ESRL and site-specific maximum air temperature averaged for the months of April-September for 2004, and calculated $c_{\mathrm{c}}$ from Equation (5) (Farquhar et al., 1982):

$$
\Delta \approx a+(b-a) \bullet \frac{c_{\mathrm{c}}}{c_{\mathrm{a}}} .
$$


We then calculated the draw-down of $\mathrm{CO}_{2}$ between the atmosphere and the chloroplast $\left(p_{\mathrm{a}}-p_{\mathrm{c}}\right)$ for betweensite comparisons of absolute differences.

\section{Meteorological and sap-flow measurements}

Meteorological data was collected at the juniper site but was not available onsite for the ponderosa and spruce sites, so the nearby Valles Caldera meteorological stations were used, approximately 6 and $1.5 \mathrm{~km}$ away from the pine and spruce sites, respectively. The meteorological station used for the ponderosa site is located at $2643 \mathrm{~m}$ a.s.l. $\left(35.8582^{\circ} \mathrm{N}, 106.5211^{\circ} \mathrm{W}\right)$, and the station used for the spruce site is located at $3231 \mathrm{~m}$ a.s.1. $\left(35.8839^{\circ} \mathrm{N}\right.$, $\left.106 \cdot 5536^{\circ} \mathrm{W}\right)$. All meteorological measurements were recorded by dataloggers: model CR10X recording hourly averages at the pine and spruce sites and model CR23X recording at half-hourly averages at the juniper site (Campbell Scientific, Logan, UT, USA). Measurements of relative humidity and air temperature were collected with a HMP45C-L (Campbell Scientific) at a height of $1.2 \mathrm{~m}$ for the juniper site, and $5 \mathrm{~m}$ for the pine and spruce sites. Precipitation at the pine site was measured with a Met One AC Heated Rain Gage (385-L, Campbell Scientific), while the stations for the spruce and juniper sites used a tipping bucket rain gage (TE525WS-L, Texas Electronics, Inc., Dallas, TX, USA) with a snowfall adapter (CS705, Campbell Scientific). At all three sites, precipitation gauges were located in open areas without overhead canopy.

We used sap-flow measurements to estimate $G_{\text {s }}$ and $E$ for the period of July-September 2005. The pine and spruce sites both had power constraints that prevented continuous sampling, so we have only used dates when all three sites had measurements. This resulted in 15 complete 24-h measurement periods at all three sites. Sap flow was measured at all three sites using the heatdissipation technique (Granier, 1987). Five trees were measured at the juniper site and ten trees were measured at both the pine and spruce sites. Trees were chosen that had diameter and height characteristics within the range of values typical for each site (Table I). For the pine and spruce sites, we placed two sensors per tree distributed on the north and south aspects, respectively. The sapwood of junipers is less symmetric than pine and spruce trees, so locating multiple sensors per bole has a high likelihood of resulting in sensors being installed into heartwood, compromising the method (Clearwater et al., 1999). Juniper trees are multi-stemmed, so to account for within-plant variation we installed two sensors per individual, with each probe installed in a separate stem. This resulted in sensors being installed at a variety of stem aspects at the juniper site.

In all species, probes were installed 1-2 $\mathrm{m}$ above the soil surface with spacing of $10 \mathrm{~cm}$ between the continuously heated upper probe and the unheated lower probe. Probe lengths varied among sites in proportion to the average sapwood depth in each species to avoid corrections required when sensor length exceeds sapwood thickness (Clearwater et al., 1999). At the juniper site, we used $10 \mathrm{~mm}$ probes while $20 \mathrm{~mm}$ probes were used at the ponderosa and mixed conifer sites. Sapwood thickness was always greater than probe length based on diameter-sapwood thickness relationships. Thermocouples located in the centre of each probe integrated the temperature along the length of the probe and were wired in opposition so that a differential measurement yielded the temperature difference between the upper and lower probes. All sensors were covered with tin and an additional layer of reflective open cell foam to minimize errors caused by vertical temperature gradients established by uneven interception of solar radiation. Each probe was measured by a data-logger (CR10X, Campbell Scientific, Logan, UT, USA) at 1 min intervals and $10 \mathrm{~min}$ averages of these values were stored for subsequent calculations.

The maximum temperature difference between probes $\left(\Delta T_{\mathrm{m}}\right)$ is a characteristic of each probe installation and should occur under conditions of zero flow. To avoid any errors associated with heating of the stem in open canopy sites (primarily the juniper site), we determined this maximum difference for each probe every day during the hours before sunrise. We used these data to determine long-term max values of $\Delta T_{\mathrm{m}}$ for use in calculation of instantaneous sap flux. Sap flux $\left(J_{\mathrm{s}} ; \mathrm{g} \mathrm{m}^{-2} \mathrm{~s}^{-1}\right)$ was determined using the empirical calibration of Granier (1985):

$$
J_{\mathrm{s}}=119 k^{1.231} \text {, }
$$

where

$$
k=\left(\Delta T_{\mathrm{m}}-\Delta T\right) / \Delta T,
$$

and $\Delta T$ is the 10-min average of the temperature difference. On average, juniper sap velocity differed by $30 \%$ between the two stems within each individual, pine sap velocity was $42 \%$ lower for north compared to south aspects of stems, and spruce sap velocity was 5\% lower for north than south aspects of stems (data not shown). Before scaling fluxes, sap velocities were averaged for the north and south aspect sensors of the pine and spruce trees and averaged between the two sampled stems of each juniper individual. Sap flux per unit sapwood area $\left(E_{\mathrm{s}}\right)$ is equivalent to $J_{\mathrm{s}}$ after conversion to molar units, and was scaled to leaf- and ground-area bases $\left(E_{1}\right.$ and $\left.E_{\mathrm{g}}\right)$ using the site-specific allometric relationships $A_{1}: A_{\mathrm{s}}$ and $A_{\mathrm{s}}: A_{\mathrm{g}}$ (Table I). Because our objective was to examine the relationship of trends between sites to the model predictions we limited our analyses to 12-h daylight total $E$, and 8-h daylight mean $G_{\mathrm{s}}$ (below), and did not conduct sub-daily comparisons.

Crown-level stomatal conductance $\left(G_{\mathrm{s}}\right)$ was calculated via a more complex version of Equation (2):

$$
G_{\mathrm{s}}=\frac{K_{\mathrm{g}}(T) E_{1}}{D}
$$

in which $K_{\mathrm{g}}$ is a conductance coefficient $(115.8+$ $0.4236 \times$ temperature, Monteith and Unsworth, 1990; Ewers et al., 2001). This calculation assumes that leaf 
temperature equals air temperature, $D$ is relatively homogeneous within the canopy, and capacitance was minor during the time period used for calculations (Ewers et al., 2001). We calculated $G_{\mathrm{s}}$ averages using data from 10:00 to $16: 00$ hours each day to maximize the likelihood of meeting these assumptions. All values are presented in $j$ the physiologically relevant molar units (Pearcy, 1989) but values of $\mathrm{mm} \mathrm{day}^{-1}$ are also presented for $E_{\mathrm{g}}$ for comparison.

\section{Modelling}

We parameterized Equations (1)-(3) first as a general model using only climate data, and second, using sitespecific structural data. For the general model, it has previously been shown that the response of gas exchange to tree size can be predicted using only tree height, $D$, and assumed values for $\Psi_{\mathrm{s}}$ (McDowell et al., 2005). In this study, we used mean daylight $D$ during the study period, and mean annual precipitation as a surrogate for $\Psi_{\mathrm{s}}$ because (1) water potential was not measured with sufficient frequency at the pine and spruce sites, and (2) soil water content was measured using different techniques and at different depths across the three sites, preventing inter-site comparison (E. Small personal communication). We assumed for the time being that all species hold $\Psi_{1}$ constant (isohydric), although we know this assumption to be false for the anisohydric juniper (West et al., 2007; McDowell et al., 2008). The isohydry assumption was supported by midday $\Psi_{1}$ measurements at the pine and spruce sites (E. Small personal communication). We consider the implications of isohydric versus anisohydric regulation of $\Psi_{1}$ in the Discussion section. The site-specific model used the same climatic parameterizations along with direct measurements of (1) $A_{1}: A_{\mathrm{s}}$ and $h$ to predict $G_{\mathrm{s}}$, and (2) $A_{\mathrm{s}}: A_{\mathrm{g}}$ and $h$ to predict $E_{\mathrm{g}}$. Sensitivity analyses of varying $k_{\mathrm{s}}$ with elevation (e.g. Maherali and DeLucia, 2001) did not result in significant differences in the model output, and so, for simplicity we held $k_{s}$ constant across sites. Comparison to the observations was facilitated by normalizing predictions relative to the highest observed values, constraining the upper limit of the predictions (Oren et al., 1999).

\section{RESULTS}

Mean annual values for selected climate parameters are presented in Table I. As expected, the climate becomes wetter and cooler with increasing elevation, with the juniper site being warmest and driest, and the spruce site the coolest and wettest. Climate characteristics during the study period of 26 July to 28 September 2005 (Day of year 207-271) were typical of the elevation transect, with the highest air temperature and $D$ at the juniper site, and lowest values at the spruce site. Daylight average, $D$, during the measurement period ranged from 1.01 to $3.48 \mathrm{kPa}$ at the juniper site, $0.49-1.95 \mathrm{kPa}$ at the pine site, and $0.55-1.48 \mathrm{kPa}$ at the spruce site. Stand-level analyses showed the pine site to have particularly high density measured as either stems per hectare or basal area (Table I). Sapwood area per unit ground area averaged $2.5,47.5(4.7)$ and $34.3(5.0) \mathrm{m}^{2} \mathrm{ha}^{-1}$ for the juniper, pine and spruce sites, respectively.

Sapwood area was strongly correlated with stem basal diameter (Figure 2(a)) and stem basal area (Figure 2(b)). The basal diameter relationships were: juniper $A_{\mathrm{s}}=$ $4.3 \times$ (diameter $)-9.8\left(r^{2}=0.68, P<0.01\right)$; pine $A_{\mathrm{s}}=$ $39.4 \times$ (diameter) $-663.0\left(r^{2}=0.97, P<0.001\right)$; and spruce $A_{\mathrm{s}}=37.8 \times$ (diameter) $-649.1\left(r^{2}=0.75, P<\right.$ 0.01). The basal area relationships were: juniper $A_{\mathrm{s}}=$ $-0.001 \times\left(A_{\mathrm{b}}\right)^{2}+0.51 \times A_{\mathrm{b}} \quad\left(r^{2}=0.99, \quad P<0.001\right) ;$ pine $A_{\mathrm{s}}=0.97 \times A_{\mathrm{b}}\left(r^{2}=0.99, P<0.001\right)$; and spruce $A_{\mathrm{s}}=0.74 \times A_{\mathrm{b}}\left(r^{2}=0.76, P<0.01\right)$. Forcing regressions of sapwood area versus basal area through the origin had negligible impact on fit statistics. The ratio of sapwood area to basal area averaged $0.40(0.03), 0.95(0.01)$ and $0.73(0.05) \mathrm{cm}^{2} \mathrm{~cm}^{-2}$ for juniper, pine and spruce, respectively.

Leaf area was strongly correlated with sapwood area for each species (Figure 3). The relationships were: juniper $A_{1}=0.26 \times A_{\mathrm{s}}-0.52\left(r^{2}=0.87, P<0.01\right)$; pine $A_{1}=0.05 \times A_{\mathrm{s}}+1.66\left(r^{2}=0.87, P<0.001\right)$; and spruce $A_{1}=0.08 \times A_{\mathrm{s}}+6.85\left(r^{2}=0.47, P<0.01\right)$. The ratio $A_{1}: A_{\mathrm{s}}$ averaged 0.24 (se 0.03$), 0.05(0.01)$ and 0.09 $(0 \cdot 01) \mathrm{m}^{2} \mathrm{~cm}^{-2}$ for juniper, pine and spruce, respectively. Using $A_{1}: A_{\mathrm{s}}$ and $A_{\mathrm{s}}: A_{\mathrm{g}}$ measurements, we calculated that canopy LAI averaged $0.57,2.38(0.23)$ and 3.09

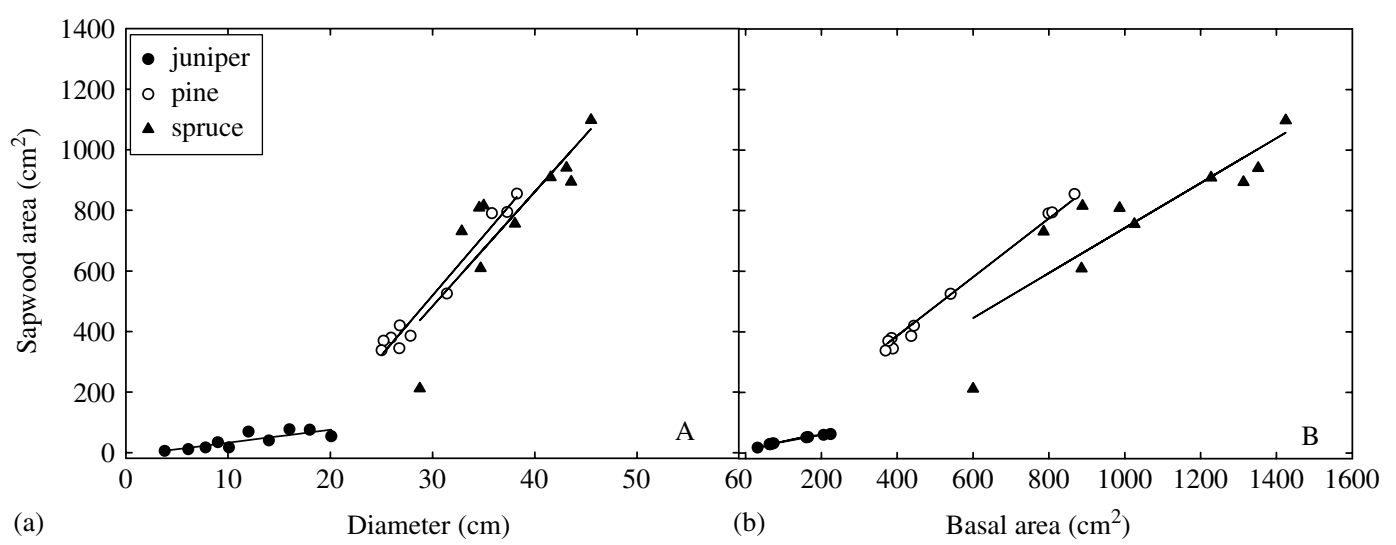

Figure 2. Sapwood area as a function of (a) diameter and (b) stem basal area for juniper, pine and spruce. Regressions are provided in the text. 
$(0.50) \mathrm{m}^{2} \mathrm{~m}^{-2}$, respectively, for the juniper, pine and spruce sites (Table I).

The carbon isotope ratio $\left(\delta^{13} \mathrm{C}\right)$ of 2005 stemwood averaged $-22.8(0.23),-24.9(0.33)$ and $-23.8(0.14) \%$ for juniper, pine and spruce, respectively $(P<0 \cdot 01)$. The trend between sites was altered only slightly after conversion to $p_{\mathrm{a}}-p_{\mathrm{c}}$ to account for the different site elevations, with values of $16.25(0.23), 12.93(0.33)$ and $13.40(0.24)$ $\mathrm{Pa}$ for juniper, pine and spruce, respectively $(P<0.01$, Table I). These results indicate that gas exchange per unit leaf area was most constrained at the juniper site and least constrained at the pine site.

Sap velocity rates during daylight hours averaged $31.1(0.4), 10.8(0.2)$ and $17.5(0.2) \mathrm{g} \mathrm{m}^{-2}$ sapwood $\mathrm{s}^{-1}$ for juniper, pine and spruce, respectively $(P=$ $0.001)$. Transpiration per unit sapwood area averaged 7.12 (0.006), 2.69 (0.002), and 4.13 (0.003), mol cm ${ }^{-2}$ sapwood day ${ }^{-1}$ for juniper, pine and spruce, respectively (Figure 4(a), $P<0.001$ ). There were no significant relationships between $E_{\mathrm{s}}$ and $D$ within species. Relationships between $E_{\mathrm{s}}$ and $D$ did exist when examined on an hourly basis although hysteresis confounded quantitative comparisons. Analysed with all species together, the relationship is: $E_{\mathrm{s}}=1.66 \times D+2.03, r^{2}=0.32, P<0.001$.

Transpiration per unit leaf area averaged 29.7 (1.68), $48.9(3.16)$ and $41.3(1.65) \mathrm{mmol} \mathrm{m}^{-2}$ leaf area day ${ }^{-1}$ for juniper, spruce and pine, respectively (Figure 4(b)). Within species, the relationships between $E_{1}$ and $D$ were significant only for spruce: $E_{1}=11.7 \times D+29.7$, $r^{2}=0.31, P=0.016$. A weak but significant relationship was observed when all species were analysed together: $E_{1}=-6.8 \times D+50.7, r^{2}=0.17, P=0.002$.

Transpiration per unit ground area increased with site elevation, averaging $18.77(0.95), 123.31(8.23)$ and 144.68 (5.69) $\mathrm{mol} \mathrm{m}^{-2}$ ground area $\mathrm{day}^{-1}$ for juniper, spruce and pine, respectively. Within species, there were no significant relationships between $E_{\mathrm{g}}$ and $D$ (Figure 5). Analysed together, the relationship was: $E_{\mathrm{g}}=-0.83 \times$ $D+2.99, r^{2}=0.48, P<0.001$. Figure 5 also shows predictions of the general hydraulic model from Figure 1 and the site-specific hydraulic model that utilized our direct measurements of $A_{\mathrm{s}}: A_{\mathrm{g}}$ and $h$. The slope of the

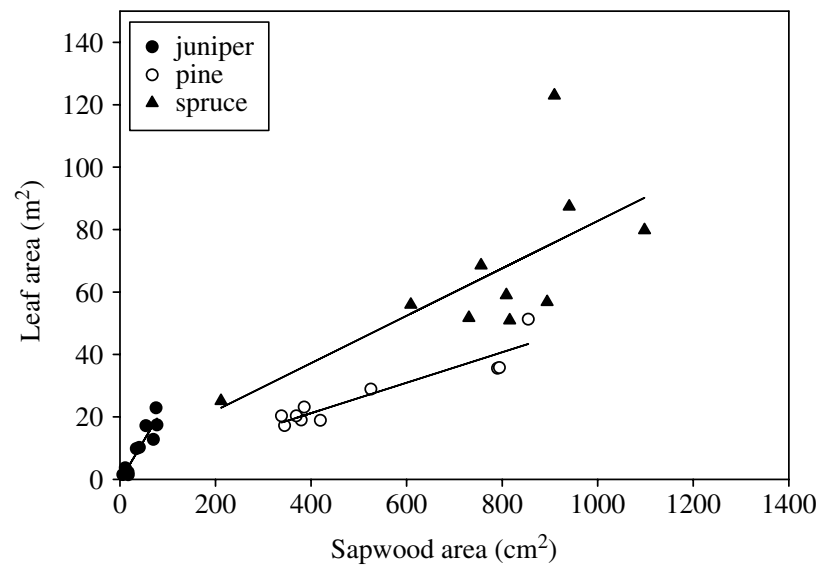

Figure 3. Leaf area as a function of sapwood area $\left(A_{\mathrm{l}}: A_{\mathrm{S}}\right)$ for of juniper, pine, and spruce. Regressions are provided in the text.

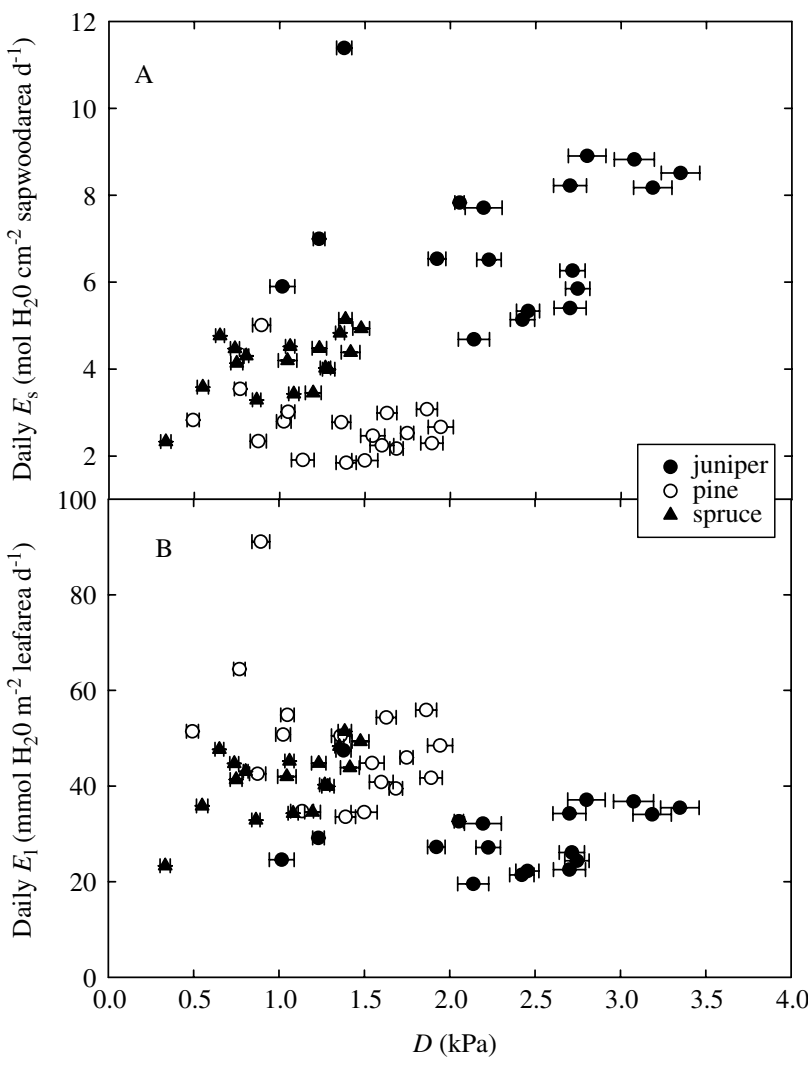

Figure 4. Observations of (a) $E_{\mathrm{s}}$ and (b) $E_{1}$ versus $D$ for juniper, pine and spruce. Bars are standard errors.

relationship for the general model is -0.86 and the slope for the site-specific model is $-1 \cdot 34$.

Crown-level stomatal conductance averaged 26.8 (3.9), $69.2(11.0)$, and $65.0(5.9) \mathrm{mmol} \mathrm{m}^{-2}$ leaf area day ${ }^{-1}$ for juniper, spruce and pine, respectively. The juniper site was significantly different from the other two sites $(P<0.001)$ but the pine and spruce sites were not statistically distinguishable $(P>0 \cdot 10) . G_{\mathrm{s}}$ declined exponentially with $D$ (Figure 6). Exponential relationships provided the best fits between $G_{\mathrm{s}}$ and $D$ (for clarity, the regression lines are not shown on the figure). Analysed within species, the relationships between $G_{\mathrm{s}}$ and $D$ were as follows: juniper $G_{\mathrm{s}}=82 \cdot 36 \mathrm{e}^{(-0 \cdot 50 \times D)}$ $\left(r^{2}=0.54, P<0.01\right)$; pine $G_{\mathrm{s}}=283 \cdot 2 \mathrm{e}^{(-1 \cdot 15 \times D)}\left(r^{2}=\right.$ $0 \cdot 84, P<0.001)$; and spruce $G_{\mathrm{s}}=173.5 \mathrm{e}^{(-0.97 \times D)}\left(r^{2}=\right.$ $0.73, \quad P<0.01)$. Analysed together the relationship is: $G_{\mathrm{s}}=147.2 \mathrm{e}^{(-0.74 \times D)}\left(r^{2}=0.80, P<0.001\right)$. Predictions from the general model (Figure 1) and the sitespecific hydraulic models that used direct measurements of $A_{\mathrm{l}}: A_{\mathrm{s}}, h$ and $D$ are shown in Figure 6. The exponents of exponential fits to these simulation points are as follows: $-0.49,-0.89$, and -1.08 for juniper, pine, and spruce, respectively. The exponent for the general model was $-1 \cdot 00$.

\section{DISCUSSION}

When examined across multiple sites and species in a watershed, it appears that short-term adjustments of $G_{\mathrm{s}}$ 


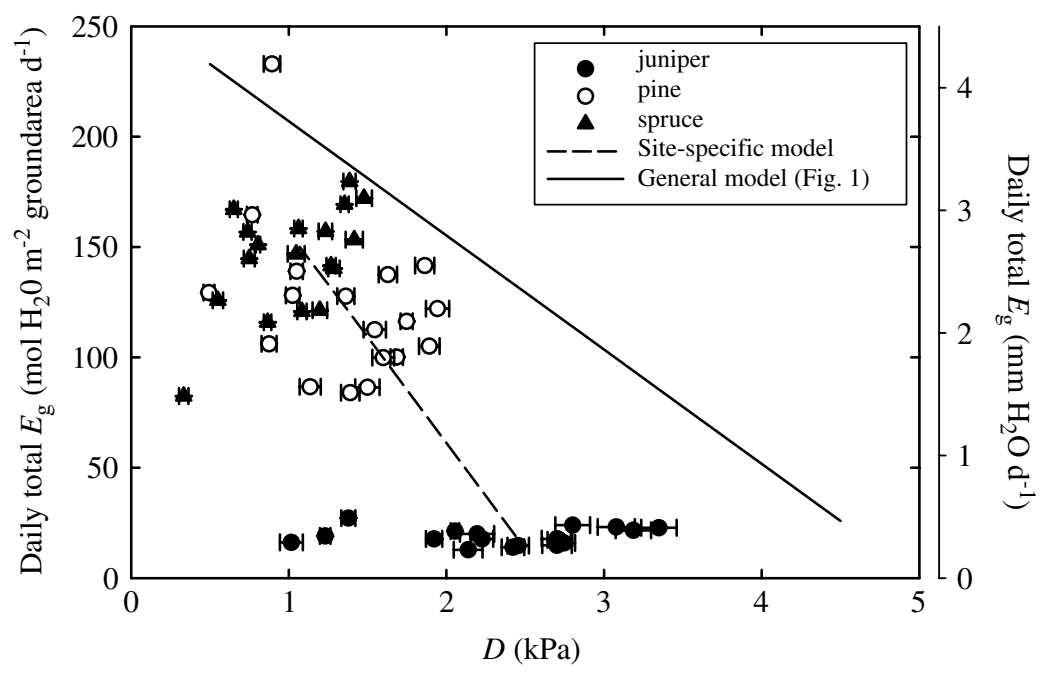

Figure 5. $E_{\mathrm{g}}$ versus $D$ for juniper, pine and spruce. Also shown are the general model from Figure 1 and the site-specific model. Equations are provided in text. Values are presented in both the units common to physiologists $\left(\mathrm{mol} \mathrm{m}^{-2} \mathrm{day}^{-1}\right)$ and hydrologists $\left(\mathrm{mm} \mathrm{day}^{-1}\right)$.

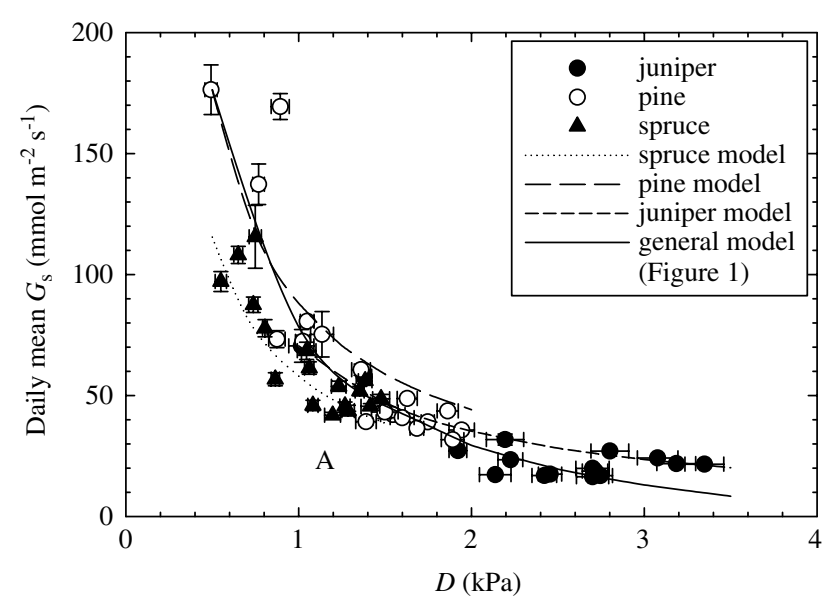

Figure 6. $G_{\mathrm{s}}$ versus $D$ for juniper, pine and spruce. The general model as well as site-specific models are overlain. Regressions of $G_{\mathrm{s}}$ versus $D$ along with the model equations are provided in the text. All data include standard error bars for $G_{\mathrm{s}}$ and $D$, some of which are not visible because they are smaller than the data symbol.

and long-term adjustments of tree and stand structures regulated $E$ within climatic limits as predicted by the simple hydraulic model. We provide the first sapwood : basal area and $A_{1}: A_{\mathrm{s}}$ estimates for juniper, pine and spruce in New Mexico (Figures 2, 3), and observed that $A_{1}: A_{\mathrm{s}}$ has significant impacts on $E$ and $G_{\mathrm{s}}$ (Figures 4, 6). The scaling denominators $A_{\mathrm{s}}, A_{\mathrm{l}}$ and $A_{\mathrm{g}}$ had major impacts on the relative ranking of $E$ between sites. Juniper trees had the highest fluxes/unit sapwood area, but juniper also had the lowest fluxes when scaled to leaf or ground area (Figures 4, 5). The pine and spruce trees were similar in $E$ per unit leaf area. Differences in $A_{\mathrm{s}}: A_{\mathrm{g}}$ across all three sites resulted in an increase in $E_{\mathrm{g}}$ with increasing elevation (Figures 4,5 ). The net effect of site-specific variation in $A_{1}: A_{\mathrm{s}}, A_{\mathrm{s}}: A_{\mathrm{g}}$ and $G_{\mathrm{s}}$ across the transect resulted in $E_{\mathrm{g}}$ consistent with predictions from the general and site-specific hydraulic models (Figures 1, 5). Variation in $G_{\mathrm{s}}$ was also consistent with predictions from the general and site-specific hydraulic models (Figures 1, 6, Table I). These results support the concept of homeostatic regulation of transpiration within climatic envelopes (Ehleringer, 1993; Oren et al., 1999; McDowell et al., 2006; Waring and Running, 2007) and are consistent with scaling studies of plant and ecosystem metabolism (Enquist et al., 1998; West et al., 1999; Enquist and Niklas, 2001).

\section{Allometic results}

The sapwood and $A_{1}: A_{\mathrm{s}}$ relationships presented in Figures 2 and 3 are the first for juniper, pine and spruce in New Mexico. Pine and spruce shared a similar relationship between sapwood area and stem diameter (Figure 2(a)) as expected based on current theory of allometric scaling of plant vascular systems (Enquist et al., 1998; West et al., 1999; Enquist and Niklas, 2001). Prior observations by Meinzer et al. (2001) confirmed this theory for 30 species of tropical trees and suggest that water limitation drives the constant scaling relationship. This conclusion was supported by Ewers et al. (2002), who observed that upland species conformed to the constant relationship between sapwood area and diameter but wetland species did not. In contrast, in our study, it was the species at the most arid site, juniper, which deviated from the expected pattern (Figure 2(a)). Juniper sapwood is asymmetric due to large sections of dead wood that form in strips along the length of the stems. This large fraction of dead wood in addition to heartwood reduces the relative fraction of the stem containing sapwood, hence lowering the ratio of sapwood per diameter.

Examination of the $A_{1}: A_{\mathrm{s}}$ and $A_{\mathrm{s}}: A_{\mathrm{g}}$ observations reveals dependencies not only on species, as expected, but also adjustments to disturbance and edaphic conditions. The juniper $A_{1}: A_{\mathrm{s}}$ observations of $0.24 \mathrm{~m}^{2} \mathrm{~cm}^{-2}$ were high relative to other estimates. Juniperus osteosperma in Oregon has $A_{1}: A_{\mathrm{s}}$ of 0.07 (Waring, 1980) and $J$. monosperma in central New Mexico has observed $A_{1}: A_{\mathrm{s}}$ of 0.06 (Yepez et al., unpublished). Both the Waring and Yepez studies were conducted at undisturbed 
sites, whereas the Los Alamos site used for this study experienced a $\sim 97 \%$ reduction in competing piñon pine trees in autumn 2002 (Breshears et al., 2005; McDowell et al., 2008). This piñon mortality reduced ecosystem LAI by at least $70 \%$ in the first year after mortality (McDowell, unpublished data). A logical response to this dramatic reduction in competing vegetation is an increase in $A_{1}: A_{\mathrm{s}}$ of the remaining trees as has been seen in a thinning study with ponderosa pine (McDowell et al., 2006).

In contrast to the juniper site, the pine site exhibited characteristics of an extremely dense stand. The observed pine site $A_{\mathrm{s}}: A_{\mathrm{g}}$ of $47.5 \mathrm{~m}^{2} \mathrm{ha}^{-1}$ and density of 1041 stems $\mathrm{ha}^{-1}$ is unusually high in comparison to presettlement conditions (Moore et al., 2003) and is near the maximum density observed for extant ponderosa pine forests in southwestern USA (Zausen et al., 2005; McDowell et al., 2006). The observed pine $A_{1}: A_{\mathrm{s}}$ of $0.05 \mathrm{~m}^{2} \mathrm{~cm}^{-2}$ is nearly identical to the $A_{1}: A_{\mathrm{s}}$ observed in dense stands with similar $A_{\mathrm{s}}: A_{\mathrm{g}}$ in a long-term thinning study in northern Arizona (McDowell et al., 2006). The estimates of $h, p_{\mathrm{a}}-p_{\mathrm{c}}, S$, and $G_{\mathrm{s}}$ suggest that the high density of the pine site may be associated with a relatively positive water balance. The trees were similar in height to the spruce trees, and height is strongly correlated with water availability (Addington et al., 2006). The pine site had the most negative $\delta^{13} \mathrm{C}$ and $p_{\mathrm{a}}-p_{\mathrm{c}}$ of the three sites, indicative of abundant water availability relative to the other sites. The ranking of species based on observations of $S$ and $G_{\mathrm{s}}$ is consistent with the $p_{\mathrm{a}}-p_{\mathrm{c}}$ results (Table I and Figure 6), lending strength to the contention that the pine site had a relatively positive water balance. The pine site is located in an alluvial valley bottom with particularly deep soils that should allow greater exploration for water (Brooks and Vivoni, 2008) whereas the spruce and juniper sites are both located on exposed topographic positions with shallow soils $(<1 \mathrm{~m})$.

The spruce estimates of $0.09 \mathrm{~m}^{2} \mathrm{~cm}^{-2}$ for $A_{1}: A_{\mathrm{s}}$ are significantly lower than those for $P$. englemanii from Colorado (0.30-0.36, Kaufmann and Troendle, 1981) and Oregon $(0.34$, Waring et al., 1982) or for other Picea species such as Picea abies (0.36, McDowell et al., 2002b) and Picea rubens (0.50, Marchand, 1984). Although it is impossible to draw conclusions about the mechanism underlying this difference, there are two factors that may influence $A_{1}: A_{\mathrm{s}}$ of the spruce site. First, this site had evidence of spruce budworm (Choristoneura occidentalis) infestation, which results in partial defoliation of the tree crowns. Although our sample trees did not have obvious evidence of infestation, it is possible that some degree of defoliation had occurred. Second, the low $A_{1}: A_{\mathrm{S}}$ values of our spruce trees may be associated with climate conditions that are drier and warmer than that of Colorado or Oregon. Climate has been shown to alter $A_{1}: A_{\mathrm{s}}$ ratios in Pinus sylvestris in sites that differ in water availability (Mencuccini and Grace, 1995), latitude (Mencuccini and Bonosi, 2001) or region (Poyatos et al., 2007).

\section{Carbon isotopes}

The $p_{\mathrm{a}}-p_{\mathrm{c}}$ estimates based on measurements of tree ring $\delta^{13} \mathrm{C}$ allow assimilation- and crown-weighted quantification of the draw-down of $\mathrm{CO}_{2}$ from the atmosphere to the site of carboxylation (e.g. Hultine and Marshall, 2000). This draw-down is driven largely by $G_{\mathrm{s}}$ but may be impacted by the conductance of $\mathrm{CO}_{2}$ from the substomatal pore into the mesophyll and by photosynthetic capacity. We cannot discount these factors because photosynthetic capacity and mesophyll conductance are both likely to vary among sites and species (e.g. Evans, 1989 and Evans et al., 1994, respectively) and we did not measure either of these parameters in our study. Thus, we regard the $p_{\mathrm{a}}-p_{\mathrm{c}}$ estimates in Table $\mathrm{I}$ as an index of constraints on gas exchange rather than a direct measure of $G_{\mathrm{s}}$. However, the similar ranking of species based on $p_{\mathrm{a}}-p_{\mathrm{c}}$ and $G_{\mathrm{s}}$ (Table I and Figure 6, respectively) indicate that $p_{\mathrm{a}}-p_{\mathrm{c}}$ is an accurate index of the relative constraints on gas exchange between sites. This result lends support to the general ranking of gas exchange across the elevation transect as juniper $<$ spruce $\leq$ pine, which is contrary to the common notion of increasing gas exchange with increasing elevation that is commonly found by isotope-elevation transect studies in southwestern USA (Van de Water et al., 2002; Adams and Kolb, 2004). Again, we hypothesize that this ranking is due to relatively positive water balance at the pine site, a hypothesis that may be tested by hydrologists working at these sites.

\section{Stomatal conductance and transpiration}

The structural differences between species and sites had a large impact on $E$ (Figures 4, 5). $E$ per unit sapwood area is negatively related to the amount of sapwood held by trees (Figures 2, 4(a)). However, the much larger $A_{1}: A_{\mathrm{s}}$ of juniper reversed this pattern after scaling $E$ to the crown, where juniper transpired less water per leaf area than pine or spruce (Figure 4(b)). Scaling $E$ to the ecosystem via $A_{\mathrm{s}}: A_{\mathrm{g}}$ resulted in spruce having the largest flux with pine intermediate and juniper lowest (Figure 5). The clear importance of $A_{\mathrm{s}}: A_{\mathrm{g}}$ on ecosystem $E$ is consistent with observations from other multi-ecosystem, multi-species comparisons (e.g. Ewers et al., 2002).

The strong differences between sites in species composition, edaphic conditions (e.g. deep alluvial soils at the pine site), disturbance history (e.g. the juniper site), and climate (Table I) should have provided a difficult, rigorous test of the theory embodied by Equations (1)-(3). Despite this inter-site variability, we observed a strong correspondence between theory and observations (Figures 5, 6). It appears that each species optimized $G_{\mathrm{s}}$ and structure homeostatically within the constraints associated with each location. In the case of ecosystem-scale $E$, observations were consistently less than predictions from the general model that was driven only by climate, though they had the same slope of $E$ versus $D$ ( -0.83 vs -0.86 for observed versus model, Figure 5). This overestimate may result because the general model applies only to ecosystems that completely 
utilize the available resources (Enquist and Niklas, 2001) and hence consume all available water. We measured only over-story transpiration but it is likely that water also evaporated from soil surface and from under-story vegetation, thus it is logical that our scaled observations of ecosystem $E$ were less than predicted from theory. This is particularly likely at the juniper site because up to $30 \%$ of the $L A I$ at this site is composed of forbs and grasses that have grown since the mortality of the piñon pine (McDowell, unpublished data), and $E$ was not quantified for this vegetation. In contrast, the site-specific model (Equation (3)) matches observations of ecosystem-scale $E$ well at all three sites because this model included $A_{\mathrm{s}}: A_{\mathrm{g}}$, hence the model and observations had a similar basis for comparison. Thus it appears that the components of the model, namely $h, A_{\mathrm{s}}: A_{\mathrm{g}}$ and $\Psi_{\mathrm{s}}-\Psi_{\mathrm{l}}$, are sufficient to capture the general patterns of ecosystem-scale $E$ across this elevation transect.

The agreement between observations and predictions of $G_{\mathrm{s}}$ (Figure 6) for the general and site-specific models also suggests that the general hydraulic model captures the key parameters driving $G_{\mathrm{s}}$. It is important to note that the strong correspondence between theory and predictions is due in part to the fact that $G_{\mathrm{s}}$ is calculated using $D$ (Equation (8)) so the exponential pattern is to be expected. This is similar to the tight relationships shown when conducting sensitivity analyses of stomatal conductance to $D$ (e.g. Oren et al., 1999; Ewers et al., 2005, 2007). However, the similarity in the exponents of the predicted and observed relationships between $G_{\mathrm{s}}$ and $D$ along with the similarity between predictions and the independent $p_{\mathrm{a}}-p_{\mathrm{c}}$ results (Table I) suggests that the parameters $h, A_{1}: A_{\mathrm{s}}$ and $\Psi_{\mathrm{s}}-\Psi_{\mathrm{l}}$, are sufficient to capture the general $G_{\mathrm{s}}$ and gas exchange patterns across this elevation transect. We suspect that the prediction from Equation (1) would have been less successful at the juniper site had we considered the pre-monsoon period when soil water content is low and $D$ is above $4 \mathrm{kPa}$. Anisohydric species, species that allow $\Psi_{1}$ to decline with increasing $D$ rather than holding $\Psi_{1}$ constant (isohydric), may exhibit less sensitivity of $G_{\mathrm{s}}$ to $D$ (Oren et al., 1999; McDowell et al., 2008). Furthermore, Oren et al. (1999) showed that $G_{\mathrm{s}}$ sensitivity declines if the range of $D$ considered exceeds $4 \mathrm{kPa}$. Juniper trees at the study site are anisohydric; however, the period of this study was during the monsoon season when precipitation was abundant and $D$ did not exceed $4 \mathrm{kPa}$. The juniper trees at this site display anisohdric $\Psi_{1}$ only during drought, and return to $\Psi_{1}$ values similar to pine and spruce during the summer monsoon (West et al., 2007; McDowell et al., 2008). However, Equation (1) can be parameterized to allow anisohydric $\Psi_{1}$ behaviour, thus with sufficient knowledge of $\Psi_{1}$ the model will still capture the key drivers of $G_{\mathrm{s}}$ and $E$, as shown by Oren $e t a l$. (1999).

Questions remain regarding applications of the hydraulic model for prediction of transpiration that should be the considered in future research. In monsoon-driven, semi-arid systems, pulse rain events play a large role in plant water relations (Huxman et al., 2004). The ability of the hydraulic model to predict such responses has not been tested. In wetter systems where light and nutrients are more limiting than water, it appears that the hydraulic model does not adequately capture the driving factors (McDowell et al., 2002b; CalvaAlvarado et al., in press). Though these systems can be modelled using more complex ecosystem process models, a simple theoretical representation of these systems that is equivalent to Equation (1) could be useful for formulating hypotheses and interpreting patterns.

\section{CONCLUSION: THE VALUE OF HYDRAULIC MODELS TO ECOHYDROLOGY}

Our study demonstrated that a relatively simple model of plant hydraulics sufficiently captured the driving and regulatory forces for water transport across three disparate ecosystems located along a steep climatic gradient. Structural factors at the scale of individual trees and the larger ecosystem interacted with long-term climate parameters and short-term regulation by $G_{\mathrm{s}}$ to maintain $E_{\mathrm{g}}$ within an envelope predicted by the model. More complex models of the entire soil-plant-atmosphere continuum exist that may improve upon these predictions (e.g. Sperry et al., 2002).

Plant-centric models of water transport are essential tools in plant physiology for generating hypotheses and interpreting observations of biological and physical regulation of transpiration (Whitehead and Hinckley, 1991; Williams et al., 1996; Sperry et al., 2002). Similarly, basin-scale models of watershed hydrology allow hydrologists to predict and understand surface and groundwater flow and recharge (Vivoni et al., 2004; Newman et al., 2006). By combining these two approaches in a single measurement and modelling framework, ecohydrology can advance our understanding of the complex interactions and feedback loops that occur between plant and ecosystem structure and function and watershed hydrology. In particular, our results suggest that incorporating plant-scale hydraulic models of $E$ with watershed-scale hydrological models of soil moisture dynamics and $E$ may advance the predictive power of both approaches and allow better prediction of the response of plants and watersheds to climate fluctuations and change.

\section{ACKNOWLEDGMENTS}

We appreciate the field and lab assistance of Karen Brown, Heath Powers, Clif Meyer, Toti Larson, Samantha Stutz, Julie Glaser and Nicole Davidson, and the logistical support provided by Paul Brooks. We are particularly indebted to Los Alamos High School's cross-country team, which provided approximately 90 students to conduct foliage harvests over 2 days. Eric Small and two anonymous reviewers provided useful comments on an earlier version of this manuscript. This work was funded by Grants from the Office of Science (Office of 
Biological and Environmental Research), Department of Energy Grant No. DE-FG02-07ER64393, the University of California's Institute of Geophysics and Planetary Physics, and from the USDA Forest Service, Rocky Mountain Research Station, Albuquerque Office.

\section{REFERENCES}

Adams HD, Kolb TE. 2004. Drought responses of conifers in ecotone forests of northern Arizona: tree ring growth and leaf $\delta{ }^{13} \mathrm{C}$. Oecologia 140: $217-225$.

Addington RN, Donovan LA, Mitchell RJ, Vose JM, Pecot SD, Jack SB, Hacke UG, Sperry JS, Oren R. 2006. Adjustments in hydraulic architecture of Pinus palustris maintain similar stomatal conductance in xeric and mesic habitats. Plant Cell and Environment 29: 535-545.

Barnard H, Ryan MG. 2003. A test of the hydraulic limitation hypothesis in fast-growing Eucalyptus saligna. Plant Cell and Environment 26: 1235-1245.

Breshears DD, Cobb NS, Rich PM, Price KP, Allen CD, Balice RG, Romme WH, Kastens JH, Floyd ML, Belnap J, Anderson JJ, Myers OB, Meyer CW. 2005. Regional vegetation die-off in response to global-change-type drought. Proceedings of the National Academy of Sciences of the United States of America 102: $15144-15148$

Breshears DD, Myers OB, Johnson SR, Meyer CW, Martens SN. 1997. Differential use of spatially heterogeneous soil moisture by two semiarid woody species: Pinus edulis and Juniperus monosperma. Journal of Ecology 85: 289-299.

Brooks PD, Vivoni ER. Mountain Ecohydrology: quantifying the role of vegetation in the water balance of montane catchments, Ecohydrology 1: $187-192$.

Calva-Alvarado JC, Waring RH, McDowell NG. Allometric relationships with stem diameter sapwood area, and tree height to predict leaf area and foliar biomass of five wet tropical rain forest species in Costa Rica. Tree Physiology (In press).

Clearwater M, Meinzer F, Andrade J, Goldstein G, Holbrook N. 1999. Potential errors in measurement of nonuniform sap flow using heat dissipation probes. Tree Physiology 19: 681-687.

Cowan IR, Farquhar GD. 1977. Stomatal function in relation to leaf metabolism and environment. Symposia of the Society for Experimental Biology 31: 471-505.

Craig H. 1957. Isotopic standards for carbon and oxygen and correction factors for mass-spectrometric analysis of carbon dioxide. Geochimica et Cosmochimica Acta 12: 133-149.

Ehleringer JR. 1993. Carbon and water relations in desert plants: an isotopic perspective. In Stable Isotopes and Plant Carbon-water Relations, Ehleringer JR, Hall AE, Farquhar GD (eds). Academic Press: San Diego, CA; 155-172.

Enquist BJ, Brown JH, West GB. 1998. Allometric scaling of plant energetics and population density. Nature 395: 163-166.

Enquist BJ, Niklas KJ. 2001. Invariant scaling relations across treedominated communities. Nature 410: 655-660.

Evans JR. 1989. Photosynthesis and nitrogen relationships in leaves of C3 plants. Oecologia 78: 9-19.

Evans JR, von Caemmerer S, Setchell BA, Hudson GS. 1994. The relationship between $\mathrm{CO}-2$ transfer conductance and leaf anatomy in transgenic tobacco with a reduced content of Rubisco. Australian Journal of Plant Physiology 21: 475-495.

Ewers BE, Gower ST, Bond-Lamberty B, Wang CK. 2005. Effects of stand age and tree species composition on transpiration and canopy conductance of boreal forests. Plant Cell and Environment 28: $660-678$.

Ewers BE, Mackay DS, Gower ST, Ahl DE, Burrows SN, Samanta S. 2002. Tree species effects on stand transpiration in northern Wisconsin. Water Resources Research 38(7): DOI: 10·1029/2001WR000830.

Ewers BE, Mackay DS, Samanta S. 2007. Interannual consistency in canopy stomatal conductance control of leaf water potential across seven tree species. Tree Physiology 27: 11-24.

Ewers BE, Oren R, Johnsen KH, Landsberg JJ. 2001. Estimating maximum mean canopy stomatal conductance for use in models. Canadian Journal of Forest Research-Revue Canadienne De Recherche Forestiere 31: 198-207.

Farquhar GD, O'Leary MH, Berry JA. 1982. On the relationship between carbon isotope discrimination and intercellular carbon dioxide concentration in leaves. Australian Journal of Plant Physiology 9: $121-137$.
Fischer DG, Kolb TE, DeWald LE. 2002. Changes in whole-tree water relationships during ontogeny of Pinus flexilis and Pinus ponderosa in a high-elevation meadow. Tree Physiology 22: 675-685.

Granier A. 1985. Une Nouvelle methode pour la mesure du flux de seve brute dans le tronc des arbres. Annales des Sciences Forestieres 42 $193-200$.

Granier A. 1987. Sap flow measurements in Douglas-fir tree trunks by means of a new thermal method. Annales des Sciences Forestieres 44: $1-14$.

Harlow BA, Marshall JD, Robinson AP. 2006. A multi-species comparison of $\delta^{13} \mathrm{C}$ from whole wood, extractive-free wood, and holocellulose. Tree Physiology 26: 767-774.

Hill SA, Waterhouse JS, Field EM, Switsur VR, Aprees T. 1995. Rapid recycling of triose-phosphates in oak stem tissue. Plant Cell and Environment 18: 931-936.

Hubbard RM, Bond BJ, Ryan MG. 1999. Evidence that hydraulic conductance limits photosynthesis in old Pinus ponderosa trees. Tree Physiology 19: 165-172.

Hubbard RM, Ryan MG, Stiller V, Sperry JS. 2001. Stomatal conductance and photosynthesis vary linearly with plant hydraulic conductance in ponderosa pine. Plant Cell and Environment 24: 113-121.

Hultine KR, Marshall JD. 2000. Altitude trends in conifer leaf morphology and stable isotope composition. Oecologia 123: 32-40.

Huxman TE, Tissue D, Snyder K, Leffler J, Ogle K, Pockman WT, Sandquist DR, Williams DG. 2004. Precipitation pulses and carbon dynamics in semi-arid and arid ecosystems. Oecologia 141: 254-268.

Katul G, Leuning R, Oren R. 2003. Relationship between plant hydraulic and biochemical properties derived from a steady-state coupled water and carbon transport model. Plant Cell and Environment 26: 339-350.

Kaufmann MR, Troendle CA. 1981. The relationship of leaf are anad foliage biomass to sapwood conducting area in four subalpine forest tree species. Forest Science 27: 477-482.

Kutscha NP, Sachs IB. 1962. Color tests for differentiating heartwood and sapwood in certain softwood tree species, USDA Forest Service, Forest Products Laboratory Report 2246, Madison.

Lajtha K, Getz J. 1993. Photosynthesis and water use efficiency in pinyon-juniper communities along an elevation gradient in northern New Mexico. Oecologia 94: 95-111.

Leavitt SW, Long A. 1984. Sampling strategy for stable carbon isotope analysis of tree rings in pine. Nature 301: 145-147.

Leavitt SW, Long A. 1988. Stable carbon isotope chronologies from trees in the southwestern United States. Global Biogeochemical Cycles 2 $189-198$.

Leavitt SW, Wright WE. 2002. Spatial expression of ENSO, drought, and summer monsoon in seasonal $\delta{ }^{13} \mathrm{C}$ of ponderosa pine tree rings in southern Arizona and New Mexico. Journal of Geophysical Research 107: $1-10$.

Livingston NJ, Spittlehouse DL. 1996. Carbon isotope fractionation in tree ring early and late wood in relation to intra-growing season water balance. Plant Cell and Environment 19: 768-774.

Loader NJ, Robertson I, McCarroll D. 2003. Comparisons of stable carbon isotope ratios in the whole-wood, cellulose and lignin of oak tree-rings. Palaeogeography Palaeoclimatology Palaeoecology 196: 394-407.

MacFarlane C, Warren CR, White DA, Adams MA. 1999. A rapid and simple method for processing wood to crude cellulose for analysis of stable carbon isotopes in tree rings. Tree Physiology 19: 831-835.

Maguire DA, Batista JLF. 1996. Sapwood taper models and implied sapwood volume and foliage profiles for coastal Douglas-fir. Canadian Journal of Forest Research-Revue Canadienne De Recherche Forestiere 26: $849-863$.

Maherali H, DeLucia EH. 2001. Influence of climate-driven shifts in biomass allocation on water transport and storage in ponderosa pine. Oecologia 129: 481-491.

Marchand PJ. 1984. Sapwood area as an estimator of foliage biomass and projected leaf area for Abies balsamea and Picea rubens. Canadian Journal of Forest Research-Revue Canadienne De Recherche Forestiere 14: 85-87.

Marshall JD, Monserud RA. 1996. Homeostatic gas-exchange parameters inferred from $\mathrm{C}-13 / \mathrm{C}-12$ in tree rings of conifers. Oecologia 105: $13-21$.

McDowell NG, Adams HA, Bailey JD, Hess M, Kolb TE. 2006 Homeostatic maintenance of ponderosa pine gas exchange in response to stand density changes. Ecological Applications 16: 1164-1182.

McDowell NG, Barnard H, Bond BJ, Hinckley T, Hubbard R, Ishii H, Köstner B, Meinzer FC, Marshall JD, Magnani F, Phillips N, Ryan MG, Whitehead D. 2002b. The relationship between tree height and leaf area: sapwood area ratio. Oecologia 132: $12-20$. 
McDowell NG, Licata J, Bond BJ. 2005. Environmental sensitivity of gas exchange parameters in different-sized trees. Oecologia 145: 9-20.

McDowell NG, Phillips N, Bond BJ, Ryan MG. 2002a. An investigation of hydraulic limitation and compensation in large, old Douglas-fir trees. Tree Physiology 22: 763-774.

McDowell N, Pockman W, Allen C, Breshears DD, Cobb N, Kolb T, Sperry J, West A, Williams D, Yepez E. 2008. Mechanisms of plant survival and mortality during drought: Why do some plants survive while others succumb to drought? New Phytologist 178: 719-739, DOI: $10 \cdot 1111 / \mathrm{j} .1469-8137 \cdot 2008 \cdot 02436 . x$.

Meinzer F, Goldstein C, Andrade G. 2001. Regulation of water flux through tropical forest trees: Do universal rules apply? Tree Physiology 21: $19-26$.

Mencuccini M. 2003. The ecological significance of long-distance water transport: short-term regulation, long-term acclimation and the hydraulic costs of stature across plant life forms. Plant Cell and Environment 26: 163-182.

Mencuccini M, Bonosi L. 2001. Leaf/sapwood area ratios in Scots pine show acclimation across Europe. Canadian Journal of Forest ResearchRevue Canadienne De Recherche Forestiere 31: 442-456.

Mencuccini M, Grace J. 1995. Climate influences the leaf area/sapwood area ratio in Scots pine. Tree Physiology 15: 1-10.

Monserud RA, Marshall JD. 1999. Allometric crown relations in three northern Idaho conifer species. Canadian Journal of Forest ResearchRevue Canadienne De Recherche Forestiere 29: 521-535.

Monteith J, Unsworth M. 1990. Principles of Environmental Physics. Edward Arnold: London.

Moore MM, Huffman DW, Fulé PZ, Covington WW, Crouse JE. 2003. Comparison of historical and contemporary forest structure and composition on permanent plots in southwestern ponderosa pine forests. Forest Science 50: 162-176.

Newman BD, Wilcox BP, Archer S, Breshears DD, Dahm CN, Duffy CJ, McDowell NG, Phillips FM, Scanlon BR, Vivoni ER. 2006. The ecohydrology of arid and semiarid environments: A scientific vision. Water Resources Research 42: W06302, DOI:10·1029/2005WR004141.

Oren R, Sperry JS, Katul GG, Pataki DE, Ewers BE, Phillips N, Schäfer KVR. 1999. Survey and synthesis of intra- and interspecific variation in stomatal sensitivity to vapour pressure deficit. Plant Cell and Environment 22: 1515-1526.

Pearcy RW, Ehleringer JR, Mooney HA, Rundel PW (eds). 1989. Plant Physiological Ecology: Field Methods and Instrumentation. Chapman and Hall: New York.

Phillips N, Bond BJ, McDowell NG, Ryan MG. 2002. Canopy and hydraulic conductance in young, mature and old Douglas-fir trees. Tree Physiology 22: 205-211.

Poyatos R, Martinez-Vilalta J, Cermak J, Ceulemans R, Granier A, Irvine J, Kostner B, Lagergren F, Meiresonne L, Nadezhdina N, Zimmermann R, Llorens P, Mencuccini M. 2007. Plasticity in hydraulic architecture of Scots pine across Eurasia. Oecologia 153: 245-259.

Rich PM, Breshears DD, White AB. 2007. Phenology of mixed woodyherbaceous ecosystems following extreme events: net changes from differential responses. Ecology 89: 342-352.

Ryan MG, Bond BJ, Law BE, Hubbard RM, Woodruff D, Cienciala E, Kucera J. 2000. Transpiration and whole-tree conductance in ponderosa pine trees of different heights. Oecologia 124: 553-560.
Schäfer KVR, Oren R, Tenhunen JD. 2000. The effect of tree height on crown level stomatal conductance. Plant Cell and Environment 23: $365-375$.

Sperry J, Hacke U, Oren R, Comstock J. 2002. Water deficits and hydraulic limits to leaf water supply. Plant Cell and Environment 25: $251-263$.

Van de Water PK, Leavitt SW, Betancourt JL. 2002. Leaf $\delta{ }^{13} \mathrm{C}$ variability with elevation, slope, aspect and precipitation in the southwest United States. Oecologia 132: 332-343.

Vivoni ER, Grimaldi S, Nardi F, Ivanov VY, Castelli F, Bras RL, Ubertini L. 2004. Assessing Hydrological Extreme Events with Geospatial Data and Models. EOS, Transactions-American Geophysical Union 85(39): $371-375$.

Waring RH. 1980. Site, leaf area, and phytomass production in trees. In Mountain Environments and Subalpine Tree Growth, Benecke U (ed.); N. Z Forest Research Institute: Christchurch 125-135, I.U.F.R.O. Workshop, Nov. 19-30, 1979. For. Res. Inst., Christchurch, N.Z. N.Z. For. Service, For. Res. Inst. Tech. Paper No. 70.

Waring RH, Schlesinger WH. 1985. Forest Ecosystems: Concepts and Management, 1st edn. Academic Press: Orlando.

Waring RH, Running SW. 2007. Forest Ecosystems: Analysis at Multiple Scales, 3rd edn. Academic Press: San Diego, CA.

Waring RH, Schroeder PE, Oren R. 1982. Application of the pipe model theory to predict canopy leaf area. Canadian Journal of Forest Research-Revue Canadienne De Recherche Forestiere 12: 556-560.

West GB, Brown JH, Enquist BJ. 1999. A general model for the structure and allometry of plant vascular systems. Nature 400: 664-667.

West AG, Hultine KR, Jackson TL, Ehleringer JR. 2007. Differential summer water use by Pinus edulis and Juniperus osteosperma reflects contrasting hydraulic characteristics. Tree Physiology 27: 1711-1720.

Whitehead D. 1998. Regulation of stomatal conductance and transpiration in forest canopies. Tree Physiology 18: 633-644.

Whitehead D, Edwards WRN, Jarvis PG. 1984. Conducting sapwood area, foliage area, and permeability in mature trees of Picea sitchensis and Pinus contorta. Canadian Journal of Forest Research-Revue Canadienne De Recherche Forestiere 14: 940-947.

Whitehead D, Hinckley TM. 1991. Models of water flux through forest stands: critical leaf and stand parameters. Tree Physiology 9: 35-57.

Whitehead D, Jarvis PG. 1981. Coniferous forest and plantations. Water Deficits and Growth, Vol 6, Kozlawski TT (ed). Academic Press: New York.

Williams M, Rastetter EB, Fernandes DN, Goulden ML, Wofsy SC, Shaver GR, Melillo JM, Munger JW, Fan S-M, Nadelhoffer KJ. 1996. Modeling the soil-plant-atmosphere continuum in a Quercus-Acer stand at Harvard Forest: the regulation of stomatal conductance by light, nitrogen and soil/plant hydraulic properties. Plant Cell and Environment 19: 911-927.

Zausen GL, Kolb TE, Bailey JD, Wagner MR. 2005. Long-term impacts of stand management on ponderosa pine physiology and bark beetle abundance in Northern Arizona: a replicated landscape study. Forest Ecology and Management 218: 291-305. 